\title{
A Study on the Strategic Changes in Australian Lobbying Industry
}

\author{
Since the 1970's
}

\author{
Juan Zhang \\ Foreign Language Department, Qinghai Normal University \\ $38 \mathrm{Wu}$ Si West Road, Xining, Qinghai 810008, China \\ E-mail: Juanazhang2009@163.com
}

\begin{abstract}
Despite the criticisms of lobbyists as a parasitical growth on the business of government, exploiting public ignorance or reticence about the best ways to make approaches and put particular cases to political agenda, with the changes in policy advocacy environment, lobbyists have now gained wide acceptance in Australia as a legitimate and necessary channel of communication between the executive government and the community. While organized special interests are not new in Australian politics, the last decades of the $20^{\text {th }}$ century has witnessed dramatic changes in the lobbying industry in several important aspects, including the emergence of single-issue groups, the shift to research-based lobbying and the changes in lobbying strategies. This paper argues that the most extraordinary change in Australian lobbying industry seems to be that lobbying has moved from the corridors and backrooms of the Parliament to become a 'public affair'.
\end{abstract}

Keywords: Lobbying, Interest group, Pluralistic society, Agenda setting, Outsider strategies, Public relations campaigns Introduction

Once public protest and activity intended to attract media coverage was thought to be an indirect and difficult to control strategy best suited to resource-poor outsider groups with no direct access to decision-makers. Now it seems that insider groups have increasingly resorted to these outsider methods to gain influence on media reporting, public opinion and political decisions. No single event can fully explain this strategic change in lobbying industry, but the rise of new social movements, the rapid development of new technologies, and the resultant expansion of government responsibilities into new domains or previously unregulated areas are undoubtedly three of the most prominent contributing factors. The pluralization and fragmentation of social life and individual interest in particular has made the political arena "more turbulent, less predictable, less structured and more difficult to control" (Blumler and Kavanagh 1999: 211) and hence provided an incentive for more special interest groups to engage in political lobbying to make strategic gains by influencing the regulation context in which they operate.

\section{Pluralization of Australian Society and the Emergence of 'Single Issue' Groups}

The origin of political lobbying practice in Australia can be traced back to the early $19^{\text {th }}$ century when "the emergence of powerful pastoral and mercantile interests established the basis for organized pressure group activities" (Lloyd 1991: 6), but the proliferation of lobbying groups, undoubtedly occurred only by the late 1970s when "societies has become more individualistic and people are more conscious of their individual rights"(Keating 2004: 7) with the rise of new social movements. From the 1960s onwards, "[t]here are at least nine major movements: environment, ethnic, consumer, Aborigines, women, gay, peace/third world, animal rights and the New Right or neo-liberal movement, all representing a concern at some level of generality below, or different from, that of socio-economic class" (Marsh 2001: 162). These profound changes in social life not only offered people new forms of political identity but also gave rise to a great many new issues on the public agenda and accelerated the resultant formation of groups with varying size, budgets, political skills, organizational sophistication and campaigning capacities. These groups tend "to coalesce around a single issue" and often "look to a fundamental change, usually with a cultural dimension" (Lovell 1998: 354), making Australia a more pluralistic society than ever before.

The most prominent change in lobbying industry brought about by these movements is the tactics pioneered by environmentalists, feminists, gay and other activists who moved their advocacy campaigns onto the public arena. Although much of the lobbying of the new movements involved old-fashioned administrative lobbying (Warhurst 2007: 18), the range of strategies and tactics was broadened, with increasing use of grassroots lobbying and public relations campaigns (Thomas 2005: 288). Outsider strategies such as boycotts, hunger strikes, and mass marches, combined with the increasing use of modern communication technology including mass media and the Internet, are widely adopted by established interest groups who are well resourced and have ready access to policy makers. However, as is suggested by 
Kollman (1998), these strategies are adopted not for the traditional purpose of generating new members or creating the impression of popular support but because these groups understand that with the grassroots support they already have, raising issues of concern in the public arena would be a more effective strategy to push the issues onto the increasingly crowded public agenda, dramatizing long-ignored grievances, generating media attention, and getting the general public thinking about things they had not thought about before.

\section{Expansion of Government Responsibility and Research Based Lobbying}

Another important factor that has contributed to the increasing competition and policy complexity of the lobbying arena is "the historical expansion of the state's role in economy and society" (Bell 1994: 145) since the late 1970s. Despite the prevailing influence of neoliberal agenda on public policy and institutional reform across all levels of government and the commitment of neoliberal thought to smaller government, lower social spending, lower and flatter taxes, Australian federal government has maintained its influence on economic activities and become deeply involved in most aspects of life, shaping the direction and interests of outsourced businesses through regulation, assuming new responsibilities for administering biological and information technologies, moving into previously unregulated policy areas such as environmental and consumer protection or even progressively intrude into such state governments policy domains as health, education and industrial relations.

As a result, by the late 20th century, businesses 'are drowning in a sea of acts of parliament, delegated legislation, forms, non-essential procedures, licenses, cumbersome judicial interpretations, rules, regulations and administrative policy' (Ronaldson 2005: 2). With large amounts of information literally thrown at them by those clamoring for policy change or defending the status quo, policymakers feel a greater need for more professional knowledge and expertise to appropriately fulfill their legislative responsibilities than ever before and tend to focus on 'connecting solutions to problem' instead of debating whether the problems themselves deserve a response (Baumgartner and Jones 1993: 150-71). However, densely packed policy agenda, the diverse, fragmented and complex interests of the population, combined with increased public expectations for services has made policy making such a sophisticated knowledge-intensive process that the bureaucrats find themselves no longer enjoy the monopoly of specialized expertise over public policy or being capable of managing policy issues with their own skills, knowledge and expertise.

On the other hand, this proliferation of legislatures has resulted in a great expansion in the scope of lobbyists' work and dramatic changes in the way they seek to wield influence on policy outcomes. One of the challenges in the 1980 s for Australian business interests was to lift their intellectual resources and capacities to a point where they could successfully challenge the bureaucracy and, indeed, other interest groups, many of which saw the need to win arguments based on solid research intellectual rigor (Bell 1994: 146). The key point for policy advocates to retain the ear of government and to win influence is to provide not only useful information in a timely fashion but also coherent, carefully worked out policy solutions based on solid research and expertise to assist in the development of public policies. The resultant formation of the new breed specialized consulting firms with strong capacities for research, government and public relations and lobbying 'in-house' or 'for hire' consultancies alike, has well demonstrated the new trend of policy advocacy since the 1970s. This is a strategic move of lobbying from the traditional 'old boy' network to a highly specialized research-based arena, though many resource-poor 'outsiders' - community activists, street protestors and radicals - remain largely dependent on the mobilization and demonstration of public support to put pressure on politicians.

\section{Agenda Setting and Allocation of Policy Attention}

However, given the unprecedentedly crowded public agenda, the solid base of research and expertise of an argument does not necessarily guarantee its entrance into the decision making process. Policymakers are constantly bombarded with information of varying uncertainty and bias, not on a single matter, but on a multitude of potential policy topics (Jones and Baumgartner 2005: viii). What issues or dimensions of issues could successfully get on the table and become the focus of attention is in most cases characterized by uncertainty and unpredictability and will to some extent based on the group's understanding of policy agenda setting process and their capacity "to spot and seize opportunities to transform their policy ideas into public sector practice" (Mintrom 1997: 740). However, according to Pedersen and Wilkerson (2006:1041), explanations proposed by agenda-setting studies for why decision-makers focus disproportionate attention on some issues while ignoring others are wide-ranging: some are structural, emphasizing how institutions are organizes to advantage some alternatives or issues over others; some are cognitive, emphasizing how individuals or even institutions process information in ways that limit what will be addressed at any given time; others emphasize the role of external events or publics, and how they can combine with political incentives to quickly shift attention in a new direction.

Undoubtedly, this complexity and uncertainty in agenda setting process make it essential for lobby groups to recognize how in specific policy context information gets interpreted through the policy process and understand that decision makers, like all people, often ignore important changes until they become severe or until policy entrepreneurs with an interest in the matter highlight such changes (Jones and Baumgartner 2005: 7). One of the compelling reasons for even 
'insider' advocacy organizations to re-evaluate and appreciate grassroots campaigns as the theory and practice of effective strategic political communication is the realization that there are different venues, arenas, or sites that could be used to launch new policy ideas and 'highlight' their policy preferences within national policy systems and beyond. However, with interest groups, policy entrepreneurs, think tanks, political leaders, and mobilized citizens all attempting to bring different policy frames to the table, uncertainty abounds in policy process which often bears a closer resemblance to a 'garbage can' model (Cohen et al. 1972). What can be 'shook up' to the surface and been picked up by decision makers to a large extent depend on the group's strategies to make the issue politically attractive to vote-seeking politicians. It is understandable that instead of waiting patiently with well-researched proposals ready for a 'policy window' to open, a more effective way for interest groups to gain competitive advantage over other equally well-prepared policy initiatives is to actively interpret the extent and nature of environmental changes and experiment with different techniques from the public relations tool box, ranging from taking the issue to different governments or the court, to bringing the issue to the public for news coverage, public support and ultimately political attentions.

\section{Publicity Campaigns Conducted via Media}

Advances in mass communication and global technology have expanded the impact of media on the social system, increasing access to a wider range of information and decreasing the lag time between action and opinion formation (Schoenbach and Becker 1995). With their ability to rapidly and extensively transmit information across national boundaries, mass media have undoubtedly exerted substantial influence on individual's perception of world issues and the nature of their social environment especially when the information content of the media is outside the experience of individuals and others in their social network. The amount of information in modern society is so huge that people need to orient themselves in a complex world full of complex issues (Mutz 1998: 11). The charm of mass media, TV in particular in the case of Australia, is that with the expertise of a reliable source of information, they could actually shape people's preferences and orient them to the perception of which issues are important and which problems they want their government to do something about. There is plenty of evidence that people can be taught to appreciate serious news (McCombs and Reynolds 2002: 440).

During the last several decades of the twentieth century, being fully aware of the power of mass media, lobbying groups have made another change and shifted a considerable amount of their focus away from the direct contact with politicians to the mobilization of public support with the help of modern technology - the mass media and the Internet, which have made it a lot easier to organize and much cheaper to send political messages across the country overnight. To effectively push a policy issue onto the media agenda, apart from the challenge of understanding the ways in which journalists and newsrooms operate, the framing of the policy issues will in all likelihood hold the key to favorable media coverage and most importantly the attention of policy makers. As is argues by Edelman, professionals and organizations can gain power by defining the issue in such a way as to make it a serious threat to the public interest and at the same time claiming their expertise in fighting this danger. Those able 'to control definitions' of social problems have a power to 'make serious social problems seem trivial, and trivial problems seem serious' and ultimately 'benefit politically' (1988: 36). This position is so attractive that numerous interest groups are competing fiercely for gaining recognition for their particular social problem, including their particular definition of it, and having this issue placed high on the media agenda (Fog 2004: 27), with some even manufacturing artificial grassroots campaign known as 'Astroturf' to marshal support and media coverage.

It is not surprising that the media, when being attracted by the potential profit, would be more than willing to cooperate with such an interest group and run a highly emotional and attention-catching campaign about a particular social problem (Fog 2004: 27). But the risk is that once the issue debate is pushed onto the media agenda, no lobbying group could guarantee that its perception of the social issue and related policy discourse be transmitted in totality to the public. Media alteration in the massage structure and rhetoric and distortions of the theme of a lobbying issue spin are very likely to occur owing to the profit seeking nature of media coverage and its need for novelty and sensation. Nevertheless, as is noted by Craig, "pressure groups will rely on the media to different degrees, depending on their institutional links, but the declining authority of institutions and the parliamentary domain has meant that the media have become increasingly the site of political struggle." (2004: 138) The ultimate goal of putting issues on this unstructured and somewhat amorphous media agenda is to effectively mobilize key groups of constituents to influence or even "force the authorities to place the issue high on the political agenda and to implement quite drastic measures against the risk that they originally tried to downplay" (Fog 2004: 22). No politician wanting re-election could afford to ignore a sensationalist media campaign with the support of key constituents. They need to do something or to be seen doing something to satisfy the public opinion even in the rare cases when they could resist the emotional appeal and have already learned the hard facts behind the stories.

\section{Conclusion}

As is discussed above, lobbying in Australia, with the expansion in its size, range of activities and lobbying strategies and tactics, has now evolved into a highly professional activity carried out by a variety of political actors with 
specialized knowledge and expertise. These changes are mostly a direct response to the rapid social, political and scientific development and the resultant policy changes especially in the last decades of the $20^{\text {th }}$ century. Society has become more complex and pluralized and the same is true with the lobbying industry. When adapting themselves to the changed advocacy environment, interest groups have learned to exploit the opportunities presented by a policy process which is increasingly characterized by multiple opportunity structures (Richardson 2000:1006) but on the other hand 'by creating structures to control or adapt to uncertainty ... have contributed to the development of a more complex and rapidly changing policy environment' (Heinz et al. 1993: 371).

It is no longer appropriate to think of the lobbying of government as merely 'insider' activities conducted by former public servants and politicians relying on their 'old boy' connections, or simply the mobilization of grassroots campaigns to press for favorable policy change from outside. As is pointed out by Bell, interest groups no longer operate as 'one-way lobbying conduits' making demands upon government (1994: 146). What really counts for their influence is the specialized knowledge and resources that political authorities could draw upon to appropriately fulfill their policy responsibilities. Whatever changes occur, lobbying will always be a necessary part of the democratic representative political process, providing expert input into the policy making process and at the same time pressing for favorable policy outcomes with constantly modified strategies and tactics.

\section{References}

Baumgartner, F.R. and Jones, B.D. (1991). 'Agenda Dynamics and Policy Subsystems'. In Journal of Politics, 53 (4), 1044-73.

Baumgartner, F.R. and Jones, B.D. (1993). Agendas and Instabilities in American Politics. Chicago, IL: University of Chicago Press.

Bell, S. (1994). 'Australian Business Associations: New Opportunities and Challenges'. In Australian Journal of Management Vol.19 (4) 137-158.

Cohen, M.D., March, J.G. \& Olsen, J.P. (1972). ‘A Garbage Can Model of Organizational Choice'. In Administrative Science Quarterly, 17, 1-25.

Craig, G. (2004). The Media, Politics and Public Life. St Leonards: Allen \& Unwin.

Cullen, P. with an Introduction by Professor Lloyd, C. (1991). No is Not an Answer: Lobbying for Successes. Allen \& Unwin Australia Pty Ltd, NSW 2059 Australia.

Edelman, M. (1988). Constructing the Political Spectacle. University of Chicago Press.

Fog, A. (2004). The Supposed and the Real Role of Mass Media in Modern Democracy. Working paper, 2004-05-20.

Gurevitch M, Blumler JG (1990). 'Political Communication Systems and Democratic Values'. In Democracy and the Mass Media, ed. Lichtenberg, J. Cambridge University Press.

Heinz, J.P., Laumann, E.O., Nelson, R.L. and Salisbury, R. H. (1993). The Hollow Core: Private Interests in National Policy Making. Cambridge MA: Harvard University Press.

Keating, M. (2004) 'Who Rules? How Government Retains Control of a Privatized Economy'. In The Federation Press. Australia, pp.1-12

Kollman, K. (1998). Outside Lobbying: Public Opinion and Interest Group Strategies. Princeton University Press.

Lovell, D. McAllister, I. Maley, W. and Kukathas, C eds. (1998). The Australian Political System. $2^{\text {nd }}$ ed. Melbourne: Longman.

Marsh, I. (2001). 'Can the Political System Sustain the Strategic Conversations Australia Needs?'. In Australian Journal of Management, Vol. 26, Special Issue, August 2001, The Australian Graduate School of Management.

McCombs, M. \& Reynolds A. (2002). 'News Influence on Our Pictures of the World'. In: Media Effects: Advances in Theory and Research, $2^{\text {nd }}$ edition, eds. J. Bryant, D. Zillmann and E. Lawrence. Mahwah, New Jersey.

Mintrom, M. (1997). 'Policy Entrepreneurs and the Diffusion of Innovation'. In American Journal of Political Science Vol.41, 738-70.

Mutz, D. (1998). Impersonal Influence: How Perceptions of Mass Collectives Affect Political Attitudes. Cambridge: Cambridge University Press.

Pedersen, C.G. \& Wilkerson, J. (2006). 'How Agenda-setting Attributes Shape Politics: Basic Dilemmas, Problem Attention and Health Politics Developments in Denmark and the US'. In Journal of European Public Policy 13:7 September 2006: 1039-1052, Routledge: Taylor \& Francis Group.

Richardson, J. (2000). 'Government, Interest Groups and Policy Change'. In Political Studies: 2000 VOL 48, pp.1006-1025, Nuffield College, Oxford. 
Ronaldson, M. (2005). Fighting Australia's Over-regulation. A policy white paper by Senator the Hon. Michael Ronaldson. www.regulationtaskforce.gov.au/submissions/sub001.pdf.

Schoenbach, K. and Becker, L.B. (1995). 'Origins and Consequences of Mediated Public Opinion'. In Public Opinion and the Communication of Consent. Eds. T. L. Glasser and C.T. Salmon. New York: Guilford Press.

Thomas, C. (2005). 'Lobbying in the United States'. In The Handbook of Public Affairs. Eds. P. Harris and C.S. Fleisher. Sage.

Warhurst, J. (2006). 'Interest Groups and Political Lobbying'. In Government, Politics, Power and policy in Australia. eds. A. Parkin, J. Summers and D. Woodward, $8^{\text {th }}$ ed. Pearson Education.

Warhurst, J. (2007). Behind Closed Doors. UNSW press. 